\title{
The Effectiveness of Using News in Mass Media as a Learning Media of Indonesian Language in SMK Students
}

\author{
Maghfira Putri Raka ${ }^{1}$, Yakub Nasucha ${ }^{2}$, Atiqa Sabardila ${ }^{3}$, Gallant Karunia Assidik ${ }^{4}$ \\ \{arifakar81@gmail.com¹, yn254@ums.ac.id², as193@ums.ac.id $\left.{ }^{3}\right\}$ \\ Universitas Muhammadiyah Surakarta, Indonesia ${ }^{1,2,3,4}$
}

\begin{abstract}
The data source of this research is in the form of online data, namely 1. Online news 2. Non-online news that is applied at SMK. This research data in the form of words, phrases, clauses, and sentences contained in the news text as Indonesian learning media for vocational students. The data collection technique used is the note-taking technique. This study was analyzed using the referential equivalent method, referential equivalent with the hermeneutic approach, and read markers. Results of this study were found that, One, the data that was almost fulfilled in all aspects of the vocabulary and sentence building elements were only found in data 3,7 , and 8 . Two, data were found, namely three parts, namely the discourse head, discourse contents and closing discourse. Three, in the study of news text symbol found only in BTBI Kemendibud class X and XI. For BTBI class XII, no symbol was found.
\end{abstract}

Keywords: News, Vocabulary Building Elements, Discourse Structure, Review of Written Symbols, Learning Media

\section{Introduction}

Learning media, is one of the things that must be considered so that students get more motivation to enjoy learning in school. Officially, the media is a plural form of the word medium that is intended to communicate or introduction [1]. The intermediary or introduction is the nature of the media that delivers students' understanding of the material delivered by the teacher in learning at school.

Anshori and Kurniawan [2], stated that news is a fact or information written by journalists published or published in the press media, be it newspapers, magazines, tabloids, radio or television. Events are events, or events. Such news can be news, but not all news contains news. Can be natural events, such as: floods, tsunamis, volcanic eruptions, earthquakes, falling meteors, solar eclipses, fires, and so on. Newspapers are publishers consisting of institutions that publish news articles, advertisements that are published and published periodically and for sale to the public. News content in it can consist of events of war, politics and economic government, accidents, disasters, education and cultural arts. Newspapers are one of the important mass media in the distribution of information for the public.

Today, teachers also place a heavy burden on delivering subject matter about curriculum approval. However, emphasizing that does not mean the teacher has to work hard either. Teachers must have effective and efficient teaching strategies. One of the knowledges that must be possessed by teachers to work like that, it is the teacher must understand the principles of 
effective learning. Therefore, it is important for teachers to apply the principles of effective learning. One effective way of teaching is to use learning media. The teacher must be creative and active in learning media that is effectively used in learning.

Researchers provide alternative solutions in Indonesian in vocational schools in order to help and overcome problems in students and teachers who can overcome. The solution to be trialed is to use bold and courageous news media in Mass Media and learning that can be done well. Therefore, the authors took the initiative and were interested in conducting research under the title "Effectiveness of News in Mass Media as Indonesian Language Learning Media for Vocational Students".

Based on the background that has been described above, the formulation of the problem of this research is the use of Effectiveness of the Use of News in Mass Media as Indonesian Language Learning Media for Vocational Students? Furthermore, this problem is detailed as follows:

a. What is meant by fostering vocabulary and sentences in the news as a medium of Indonesian language learning for vocational students?

b. What is the explanation of the structure of news discourse as a medium of Indonesian language learning for vocational students?

c. What is the study of news writing symbols as a medium of learning Indonesian on vocational students?

This study aims to examine the Effectiveness of Using News in Mass Media as an Indonesian Language Learning Media for Vocational Students. These objectives are detailed as follows:

a. Describe the learning not builders of vocabulary and news sentences as a medium of learning Indonesian on vocational students.

b. Describe the structure of news discourse as Indonesian language learning media for vocational students.

c. Describe the review of news writing symbols as Indonesian learning media for vocational students.

\section{Methodology}

This research is a qualitative research. Qualitative research is a naturalistic study which meant that the research was conducted in natural conditions [3]. The data in this study consisted of words, phrases, clauses, and sentences contained in the news as a medium for learning Indonesian on vocational students. Research data sources consist of data that acted boldly, namely 1 . Online news that was applied at SMK, 2. Non-online news that was applied at SMK. Data collection techniques using literature study techniques.

Data analysis techniques used to discuss the complications to be studied. The data analysis technique used consisted of techniques in the equivalent method [4]. The equivalent method used is the referential equivalent. The method used in this study includes the basic technique, namely the Determination of Determination Element (PUP) technique. The thing that is used in the analysis of this PUP technique is the referential equivalent. In addition, an analysis technique is also used which also contains reading markers. Marking reading techniques are applied by looking directly at the markers available in the data. As for seeing it, it was done both syntactically and morphologically [4]. The data validity test in this study uses the theory and data triangulation. 


\section{Findings and Discussion}

This study uses the Indonesian Language Text Book (BTBI) Curriculum 2013 published by the Ministry of Education and Culture (Kemendikbud) for SMA/MA/SMK/MAK classes X, XI, and XII. The results of the study include three aspects, namely identification of the elements of vocabulary and sentence builders, description of discourse structure, and review of written symbols.

\subsection{Findings}

\subsubsection{Identification of Vocabulary and Sentence Builder Elements}

Textbooks that meet the eligibility criteria are very desirable to support the quality of learning. Textbooks can be said to be feasible if they meet the criteria of the National Education Standards Agency (BSNP). BSNP is one of the institutions formed by the government to control and assess the feasibility of textbooks circulating in the community [5]. Whether the book can be used in learning or not. According to BSNP [6], textbooks that have good quality, include four elements of eligibility, namely the feasibility of the content, the feasibility of presentation, the feasibility of linguistics, and the feasibility of graphics.

Vocabulary and sentence building elements according to BSNP [6] are included in the Feasibility of language presentation which can be seen from several aspects, namely straightforward (which includes sentence effectiveness, word accuracy and term rigidity), communicative, dialogical and interactive, ability to motivate students, and appropriateness with language rules. The results of this finding found some data in terms of vocabulary building elements and sentences in terms of the feasibility of the language presentation. The analysis results can be described as follows:

a. Data 1 (BTBI Kemendikbud Class X, pp. 9-10)

The text is entitled "Puppet", in reading this text in the form of an observation report. Data 1 of the language used is straightforward because the use of the word is appropriate, in accordance with the applicable spelling. Already using dialogic and interactive language which means that the presentation is open and interconnected between reading the news text with the available material. For example, in assignment 1 there is a command "Make questions related to the Wayang report!" The sentence shows that between the news text titled Wayang with Task 1 has used dialogical and interactive language. Has been able to motivate students and develop interest in reading it. The language is also in accordance with the accuracy of the applicable and standard grammar.

b. Data 2 (BTBI Kemendikbud Class X, pp. 16-17)

The text titled "D 'Museum Angkut Mask", in reading this text is still in the form of an observation report. This data 2 language used there are some that are less straightforward. The example of the word "VOC Coins and Conservation" is still unclear and in the glossary the word is also not explained. Already using dialogic and interactive language which means that the presentation is open and interconnected between reading the news text with the available material. Has been able to motivate students and develop interest in reading it. For example, after reading the text entitled "D 'Museum Angkut Mask" there is a command "after reading the text above, answer the question below correctly!" The sentence shows that demanding students to read the whole sera in order to answer the command correctly. The language is also in accordance with the accuracy of the applicable and standard grammar. 
c. Data 3 (BTBI Kemendikbud Class X, pp. 56-57)

The text is entitled "Development and Environmental Disasters", in the reading of this text in the form of an observation report. Data 3 is the language used is straightforward because the use of the word is appropriate, in accordance with the applicable spelling. Already using dialogic and interactive language which means that the presentation is open and interconnected between reading the news text with the available material. Has been able to motivate students and develop interest in reading it. The language is also in accordance with the accuracy of the applicable and standard grammar.

d. Data 4 (BTBI Kemendikbud Class XI, pp. 13-15)

The text is entitled "Tips for Job Interview", in the reading of this text in the form of procedure text. Data 4 is the language used is straightforward because the use of the word is appropriate, in accordance with applicable spelling. Already using dialogic and interactive language which means that the presentation is open and interconnected between reading the news text with the available material and is already supposed to read the procedure text. Has been able to motivate students and develop interest in reading it. An example of selecting a news text titled "Job Interview Tips" is suitable to be a reading of the procedure text because at the grade XI level, especially vocational high schools, they already think of work and need materials for vocational graduates. The language is also in accordance with the accuracy of the applicable and standard grammar.

e. Data 5 (BTBI Kemendikbud Class XI, pp. 48-50)

The text entitled "Mass Demonstrations", in the reading of this text in the form of explanatory text. Data 5, there are several languages that are not straightforward. Example: the first paragraph, sentence 3 "hunger society, nodding and saying yes" still contains words that are figuratively meaningful. There are sentences that are less effective. Example: Third paragraph, first sentence "the problem is then, which opinion is correct; the regent or students or other components of society?" because the sentence is a question sentence. Less effective in using valid and standard sentence sentences. Already using dialogic and interactive language which means that the presentation is open and interconnected between reading the news text with the available material and already represents the reading of explanatory text. But it is not suitable to be used as a reading that is able to motivate students and develop a reading interest in vocational children because at that age, they are vulnerable to imitating inappropriate behavior.

f. Data 6 (BTBI Kemendikbud Class XI, pp. 59-60)

The text titled "Aceh Earthquake", in the reading of this text is still in the form of explanatory text. Data 6 is the language used straightforward because the use of the word is appropriate, in accordance with the applicable spelling. Already using dialogic and interactive language which means that the presentation is open and interconnected between reading the news text with the available material. Has been able to motivate students and develop interest in reading it. The language is also in accordance with the accuracy of the applicable and standard grammar.

g. Data 7 (BTBI Kemendikbud Class XII, pp. 93-94)

The text, entitled "Rio Wants to be the Main Racer", reads this text in the form of Editorial Text. Data 7 is the language used is straightforward because the use of the word is appropriate, in accordance with the applicable spelling. Already using dialogic and interactive language which means that the presentation is open and interconnected between reading the news text with the available material. Has been able to motivate students and develop interest in reading it. The language is also in accordance with the accuracy of the applicable and standard grammar. 
h. Data 8 (BTBI Kemendikbud Class XII, pp. 103-104)

The text is entitled "Many Indonesian Workers are Incompetent", in reading this text in the form of Editorial Text. Data 8 is the language used is straightforward because the use of the word is appropriate, in accordance with the applicable spelling. Already using dialogic and interactive language which means that the presentation is open and interconnected between reading the news text with the available material. Has been able to motivate students and develop interest in reading it. The language is also in accordance with the accuracy of the applicable and standard grammar.

i. $\quad$ Data 9 (BTBI Kemendikbud Class XII, pp. 137-139)

The text is entitled "Pak Raden and Multiculturalistic Stories", in the reading of this text in the form of Articles. Data 9 is the language used is straightforward because the use of the word is appropriate, in accordance with applicable spelling. Already using dialogic and interactive language which means that the presentation is open and interconnected between reading the news text with the available material. Has been able to motivate students and develop interest in reading it. The language is also in accordance with the accuracy of the applicable and standard grammar.

\subsubsection{Description of Discourse Structure}

Discourse comes from Latin, namely discourse or discourse which means a unit of language that is greater than the sentence. Sentences or sentences turn out to be just elements forming larger units of language called discourse [7]. In the study of discourse, the focus can start from the structure of discourse. The structure of discourse is divided into three parts, namely the head of the discourse, the body of the discourse, and the discourse cover. Furthermore, it is explained that discourse is the most complete and highest language unit above a sentence or clause with high coherence and continuous cohesion and has a real beginning and end and is able to be conveyed orally and in writing.

Alwi et al. [8], explaining the elements of cohesion and coherence is the relationship of relations between propositions that are stated explicitly by grammatical and semantic elements in the sentences that form discourse. Furthermore, Guntur [9], explains the structure of discourse divided into three parts, namely beginning/abstract, middle/orientation, and end/code. As a structure, each part of the discourse has its own function. The initial part of the discourse serves as an opening discourse, the body part/middle of the discourse serves to explain the contents of the discourse, and the final part/discourse code containing the cover serves as a marker of the end of the discourse.

a. Data 1 (BTBI Kemendikbud Class X, pp. 9-10)

In the Beginning of the Discourse the title "Wayang" is read in this text in the form of an observation report. Then it contains a Wayang explanation literally. In the body or middle/orientation the discourse contains the types of Wayang. closing the observation text.

b. Data 2 (BTBI Kemendikbud Class X. pp. 16-17)

In the Beginning of the Discourse the title "D'Topeng Museum Angkut" is in the reading of this text in the form of an observation report. Then it contains an explanation of the location of the tourist attractions D'Topeng.

c. Data 3 (BTBI Kemendikbud Class X, pp. 56-57)

At the beginning of the Discourse contains the title "Development and Environmental Disasters" in the reading of this text in the form of an exposition report. Then it contains an explanation of the opinion of the earth's current conditions. the earth is of concern, the final 
part of the code contains the reaffirmation that the earth problem is a serious problem, the latter part functions as the closing text of the exposition.

d. Data 4 (BTBI Kemendikbud Class XI, pp. 14-15)

At the beginning of the Discourse contains the title "Tips for Job Interviewing" in the reading of this text in the form of procedural texts. Then it contains an explanation of the interview in a literal way. The final/code contains conclusions from the interview stages, and the final part functions as the closing procedure text.

e. Data 5 (BTBI Kemendikbud Class X1, pp. 48-50)

At the beginning of the Discourse contains the title "Mass Demonstrations" in the reading of this text in explanatory text, then contains a general description of the demonstration, why the demonstration, and how the process of the demonstration occurred. In the body or middle/orientation of the discourse contains the contents of the demonstration process and detail cause and effect of the demonstration. In the last part/code contains the conclusions of the mass demonstration. The latter part functions as a closing explanatory text.

f. Data 6 (BTBI Kemendikbud Class X1, pp. 59-60)

At the beginning of the Discourse contains the title "Aceh Earthquake" in the reading of this text in explanatory text. Then it contains a general description of the Aceh earthquake occurred, why the earthquake occurred and how the process of the earthquake occurred. On the body or middle/orientation the discourse contains the contents of the Aceh Earthquake process. and detailing the causes and consequences of the Aceh Earthquake. In the last part/code it contains conclusions about the occurrence of the Aceh Earthquake. The final part serves as the closing text of the explanation.

g. Data 7 (BTBI Kemendikbud Class X1I, pp. 93-94)

At the beginning of the Discourse contains the title "Rio Wants to Be a Racer" in the reading of this text in an editorial text, then contains a general statement of Rio's conditions wanting to become a racer on the body or middle/orientation of the discourse contains the contents of concrete evidence of the state or opinion that states the seriousness of Rio wants Becoming a racer at the end/code it contains an affirmation that the Rio wants to be the main racer. The final part functions as a closing editorial text.

h. Data 8 (BTBI Kemendikbud Class X1I, pp. 103-104)

At the beginning of the Discourse contains the title "Many Indonesian Workers Are Not Competent" in reading this text in an editorial text. Then contains a general statement of the condition of an incompetent Indonesian Workers. Incompetent Indonesian Workers The final part/code contains an affirmation of the incompetent Indonesian Workers, the final part functions as a closing editorial text.

i. Data 9 (BTBI Kemendikbud Class X1I, pp. 137-139)

At the beginning of the Discourse contains the title "Pak Raden and Multiculturalallistic stories" in the reading of this text in the form of Articles. Then contains Pak Raden's general statements and multiculturalallistic stories. On the body or middle/orientation of the discourse contains the contents of concrete evidence of the state or opinion that states $\mathrm{Mr}$. Raden and the multiculturalallistic story of the Indonesian workers the final part/code contains an affirmation that Pak Raden and the Multiculturalallistic story end up functioning as the concluding text of the article. 


\subsubsection{Review the Writing Symbols}

Study of Simbo Writing also according to BSNP [6] included in the Eligibility of the presentation of the language that can be seen from the depiction of symbols or icons must be consistent between parts of the book.

a. Data 1-6 (BTBI Kemendikbud Class X and XI).

b. Data 1-6 is found in every writing "tugas"

c. Data 7-9 (BTBI Kemendikbud Class XII) at each writing "Task", no symbol was found.

\subsection{Discussion}

\subsubsection{Identification of Vocabulary and Sentence Builder Elements}

From the data that has been found, the vocabulary and sentence building elements meet several aspects, namely straightforward which includes the effectiveness of the sentence, the accuracy of words and the rigidity of terms), communicative, dialogic and interactive, the ability to motivate students, and compatibility with language rules.

This finding data is supported or strengthened using a readability indicator from the news text used in learning. Fry Graph is the basis in measuring the level of text readability. The fry chart was originally used to measure readability with English text objects. At this end the Indonesian text can also use fry charts to measure the readability of the text. There is a difference in the measurement of the English text and the Indonesian language. In the measurement of the Indonesian text that is multiplying the results of the syllable calculation by the number 0.6. This figure is derived from the results of research that obtained evidence that the comparison between the number of English syllables with the number of Indonesian syllables is 6:10 (6 syllables in English equals 10 syllables in Indonesian.

The results of these measurements are approximate. Deviations in the measurement may occur, either sliding up or down. Therefore, the readability of the text should be added or subtracted by one point or one rank. For example, the readability results in rank 5 are not absolute results in rank 5. However, the results can be shifted one rank above that is 6 or the results shifted rank below that is 4 .

How to calculate text readability with this fry chart using a sample of 100 words in the text. Out of 100 words count the number of sentences and syllables. The line meeting between the number of sentences and the number of syllables shows the readability value of the text. In the Indonesian text the number of syllables per 100 words is multiplied by 0.6 to get the results.

Table 1. BTBI Ministry of Education and Culture class X, XI, XII

\begin{tabular}{cccccc}
\hline No & $\begin{array}{c}\text { Number } \\
\text { of words }\end{array}$ & $\begin{array}{c}\text { Number of } \\
\text { Sentences }\end{array}$ & $\begin{array}{c}\text { Number of } \\
\text { Multiplication }\end{array}$ & $\begin{array}{c}\text { Syllables 0.6 in Indonesian } \\
\text { text Number of syllables }\end{array}$ & $\begin{array}{c}\text { Number of } \\
\text { syllables }\end{array}$ \\
\hline 1 & 100 & 6 & 240 & 0.6 & 144 \\
2 & 100 & 6 & 223 & 0.6 & 133.8 \\
3 & 100 & 5 & 266 & 0.6 & 159.6 \\
4 & 100 & 7 & 268 & 0.6 & 151.8 \\
5 & 100 & 7 & 171 & 0.6 & 102.6 \\
6 & 100 & 8 & 256 & 0.6 & 153.6 \\
7 & 100 & 5 & 249 & 0.6 & 156 \\
8 & 100 & 7 & 271 & 0.6 & 162.6 \\
9 & 100 & 6 & 260 & 0.6 & 156 \\
\hline
\end{tabular}


Data 1 from a sample of 100 words with the number of sentences 6 syllables 240 multiplied by 0.6 is equal to 144 . The meeting point between the number of sentences and syllables shows readability at rank 7 almost 8 . The results of this legibility can shift to rank 9 or rank 6 . Based on these results it can be said that the text used by class $\mathrm{X}$ but the readability value is not at rank $\mathrm{X}$ but the readability of rank 7 is almost 8 or the reading material is appropriate to use class $7 / 8$. It can be said that the text is not appropriate for the $\mathrm{X}$ grade Vocational teaching materials.

Data 2 from a sample of 100 words with the number of sentences 6 syllables 223 multiplied by 0.6 equals 133.8 The meeting point between the number of sentences and syllables shows readability at rank 7 . The results of this readability can shift to rank 8 or rank 6 . Based on these results it can be said the text used by class $\mathrm{X}$ but the readability value is not in rank $\mathrm{X}$ but the readability for rank 7 or the reading material is appropriate for class 7 . It can be said that the text is not appropriate for teaching materials in class $\mathrm{X}$ vocational high school.

Data 3 from a sample of 100 words with the number of sentences 5 syllables 266 multiplied by 0.6 is equal to 159.6 . the meeting point between the number of sentences and syllables indicates readability at rank 11 . The results of this readability can shift to rank 12 or rank 10 . Based on these results it can be said that the text used by class $\mathrm{X}$ readability value is already at rank X. Can be said the text is correct used in class X vocational teaching materials.

Data 4 from a sample of 100 words with the number of sentences 7, 268 syllables multiplied by 0.6 equals 151.8 the meeting point between the number of sentences and syllables indicates readability at rank 9 . The results of this readability can shift to rank 10 or rank 8 . However, the meeting point approaches invalid area. Based on these results it can be said that the text used by class XI but the reading value is not at rank XI but the readability of rank 9 or reading material is appropriate for class 9 . It can be said that the text is not appropriate for teaching materials in class XI vocational schools.

Data 5 from a sample of 100 words with the number of sentences 7 , syllable 171 multiplied by 0.6 equals 102.6 where the meeting point between the number of sentences and syllables shows invalid in the long sentence. Based on these results it can be said the text used by class XI but the readability value is invalid or illegible. Clearly it can be said that the text is not appropriate for use in teaching materials for grade XI vocational schools or even for any class.

Data 6 from a sample of 100 words with the number of sentences 8, syllables 256 multiplied by 0.6 is equal to 153.6 meeting points between the number of sentences and syllables indicating readability at rank 8 . The results of this readability can shift to rank 9 or rank 7 . However, the meeting point approaches invalid area. Based on these results it can be said that the text used by class XI but the readability value is not at rank XI but the readability of rank 8 or the reading material is appropriate for class 8 . It can be said that the text is not appropriate for teaching materials in class XI vocational schools. Data 7 from a sample of 100 words with the number of sentences 5, syllables 249 multiplied by 0.6 is equal to 156 . the meeting point between the number of sentences and syllables shows readability at rank 10. The results of this readability can shift to rank 11 or rank 9. . Based on these results it can be said that the text used by class XII has readability rating of XII rank. It can be said that the text is used correctly in class XII vocational teaching materials.

Data 8 from a sample of 100 words with the number of sentences 7 , syllable 271 multiplied by 0.6 equals 162.6 . the meeting point between the number of sentences and syllables indicates readability at rank 11 . The results of this readability can shift to rank 12 or rank 10 . However, the meeting point approaches invalid area. Based on these results it can be said the text used by class XII. the readability value is ranked XII. It can be said that the text is used correctly in class XII vocational teaching materials. 
Data 9 from a sample of 100 words with the number of sentences 6, 260 syllables multiplied by 0.6 equals 156 . The meeting point between the number of sentences and syllables shows readability at rank 10 . The results of this readability can shift to rank 11 or rank 9 . Based on these results can it is said to be the text used by class XII but the readability value is not in rank XII but the readability for rank 10 or the reading material is appropriate for use in class 10. It can be said that the text is not appropriate for teaching materials in class XII vocational high schools.

This finding is supported by various previous studies, such as the following. Another study was conducted by Fatima, Kazim and Sultan [10]. The study identified how well the pre-use textbooks fit the learning program needs and how many activities are appropriate. The results show some problematic areas that textbooks need to improve on the four skills and cultural representation. The difference with research conducted by researchers is that researchers only focus on the first problem formulation of the vocabulary and sentence building elements, while the research conducted by Gul Fatima et al focuses on textbook analysis and evaluation in accordance with a particular context. The equation lies in the object used which is the same using textbooks that are analyzed based on.

Thus, data that are almost fulfilled in all aspects of the vocabulary and sentence builder elements are only found in data 3, 7, and 8. Apart from these data there are deficiencies in the straightforward aspects and ability to motivate students which are reinforced by the readability indicator of fry charts.

\subsubsection{Description of Discourse Structure}

This finding is supported by research by Rambing [11]. This research identifies and analyzes the seven norms contained in the 16th presidential speech discourse of the United States of America. This speech was titled "Address at Gettysburg, Pennsylvania, November 19, 1863 ". The equation with this research is about analyzing the structure of discourse.

The author concludes that the structure of the discourse in the news text consists of three parts, namely the head of the discourse, the body or content of the discourse and the closing or the final part of the discourse. The discourse head functions as a title or opening. The body or contents of discourse explaining the contents of discourse. Furthermore, the closing or the final part of the discourse functions the conclusion or reaffirmation of the discourse.

\subsubsection{Review the Writing Symbols}

Study of Simbo Writing also according to BSNP [6] included in the Eligibility of the presentation of the language that can be seen from the depiction of symbols or icons must be consistent between parts of the book.

The author concludes that symbol writing is only found in BTBI Kemendibud class X and XI. For BTBI kites XII, no symbol was found.

\section{Conclusions}

Based on data exposure, the results of the study found several conclusions.

a. The vocabulary and sentence builder elements in this study are aspects that are straightforward which include sentence effectiveness, word accuracy and term rigor), communicative, dialogic and interactive, the ability to motivate students, and compatibility 
with language rules. Data that is almost fulfilled in all aspects of the vocabulary and sentence building elements are only found in data 3,7 , and 8 .

b. The structure of the discourse in the news text consists of three parts, namely the head of the discourse, the body or content of the discourse and the closing or the final part of the discourse. The discourse head functions as a title or opening. The body or contents of discourse explaining the contents of discourse. Furthermore, the closing or the final part of the discourse functions the conclusion or reaffirmation of the discourse.

c. Writing symbols are only found in BTBI Kemendibud class X and XI. For BTBI kites XII, no symbol was found.

\section{References}

[1] A. S. Sadiman, "Media Pendidikan,” Jakarta Raja Graf. Persada, 2008.

[2] D. S. Anshori and K. Kurniawan, "Bahasa Jurnalistik," Bandung. Pus. Stud. Literasi, 2005.

[3] Sugiyono, Metode Penelitian Kuantitatif, Kualitatif, dan Kombinasi, Alfa Beta. Bandung, 2012.

[4] Sudaryanto, Metode dan aneka teknik analisis bahasa: Pengantar penelitian wahana kebudayaan secara linguistis. Duta Wacana University Press, 1993.

[5] M. Mansur, "Text Book Writing: Dasar-dasar Pemahaman, penulisan dan pemakaian Buku Teks," Jogjakarta: Ar-Ruzz Media, 2010.

[6] BSNP, Pedoman Penyusunan Kurikulum Tingkat Satuan Pendidikan Jenjang Sekolah Menengah Atas. Jakarta: BSNP, 2008.

[7] C. Abdul, "Linguistik Umum Cetakan ke Tiga," Jakarta: Bhineka Cipta, 2007.

[8] H. Alwi, S. Dardjowidjojo, H. Lapoliwa, and A. M. Moeliono, "Tata bahasa baku bahasa Indonesia," 2019.

[9] H. T. Guntur, "Menulis sebagai suatu keterampilan berbahasa." Bandung: Angkasa, 2008.

[10] G. Fatima, S. K. Shah, and H. Sultan, "Textbook analysis and evaluation of 7th \& 8th Grade in Pakistani context," Int. J. English Lang. Teach., vol. 3, no. 4, pp. 79-97, 2015.

[11] A. R. Rambing, "Analisis Wacana Pada Pidato Abraham Lincoln 'Address at Gettysburg, Pennsylvania. November 19, 1863,” J. Elektorinik, vol. 3, no. 1, 2014. 